\title{
Intervention and resistance: institutional environment and local level autonomy in LEADER. A comparative study
}

\section{Beavatkozás és ellenállás: intézményi környezet és helyi autonómia a LEADER-ben. Összehasonlító elemzés}

\author{
ELIZABETH BROOKS, KATALIN KOVÁCS
}

\begin{abstract}
Elizabeth BROOKS: research associate, School of Architecture, Planning and Landscape, Newcastle University; Henry Daysh Building, Claremont Road, Newcastle upon Tyne, NE1 7RU; elizabeth.brooks1@newcastle.ac.uk; elizabeth.brooks@virgin.net; https://orcid.org/ 0000-0001-7692-3221

Katalin KOVÁCS: senior research fellow, Institute for Regional Studies, Centre for Economic and Regional Studies; Tóth Kálmán u. 4., H-1097 Budapest, Hungary; kovacs.katalin@krtk.hu; https://orcid.org/0000-0003-1690-2570
\end{abstract}

KEYWORDS: LEADER; decentralization; local autonomy; local democracy; participation

ABSTRACT: In 2010, when hope emerged that the new conservative government would improve the governance of the LEADER Programme, the Naturama Alliance, a network of seven Hungarian Local Action Groups (LAGs), issued a Declaration that summarized procedural issues to be addressed by a revision. ${ }^{1}$ After introducing the alliance, the first chapter was entitled "Decentralization and Autonomy", indicating the direction of the desired shift towards a more autonomous operation. The LEADER Programme is scrutinized in this article from the point of view of autonomy and local democracy, exploring to what extent these are linked with or distinct from higher level governance transformations towards decentralization or recentralization.

Theoretical approaches derived from rural and government studies are interpreted in the first sections of the paper, exploring the debate regarding the correlation of autonomy and local democracy and the way it is manifested in LEADER. Most authors regard LEADER as a promoter of local democracy and identify a positive correlation between democracy and an enhanced local autonomy. However, a consensus among scholars also seems to be unfolding from these studies suggesting that the scope of 'LEADER democracy' is mostly narrow, restricting participation to more resourceful social groups due both to the 'thematic filters' of the Local Development Strategy and to 'procedural filters', such as capacities allocated to the staff for animation and assistance to overcome difficulties of application.

The empirical research background of this article is provided by two case studies, which were conducted in 2018-2019, one in England (Northumberland Uplands) and one in Hungary (Balaton Uplands), two states with complex recent histories and trajectories in terms of devolution of governance to lower levels and local autonomy. The secondary interpretation of these case studies focuses on the degree of participation and autonomy of LAGs. The analysis reveals that the degree of autonomy (and to some extent of participation) declined in both countries in the last iteration compared to the 2007-2013 programming cycle. It has also been uncovered that rather than the 'post transition', recentralized Hungarian context, it was the British institutional system and governance tradition that permitted more top-down intervention and less autonomy for the LAGs.

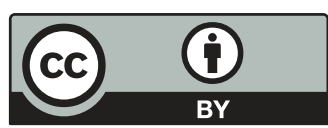


BROOKS, Elizabeth: tudományos munkatárs; School of Architecture, Planning and Landscape, Newcastle University; Henry Daysh Building, Claremont Road, Newcastle upon Tyne, NE1 7RU; elizabeth.brooks1@newcastle.ac.uk; elizabeth.brooks@virgin.net; https://orcid.org/0000-0001-7692-3221 KOVÁCS Katalin: tudományos fömunkatárs; Közgazdaság- és Regionális Tudományi Kutatóközpont, Regionális Kutatások Intézete; 1097 Budapest, Tóth Kálmán utca 4.; kovacs.katalin@krtk.hu; https:// orcid.org/0000-0003-1690-2570

KULCSSZAVAK: LEADER; decentralizáció; helyi autonómia; helyi demokrácia; részvétel

ABSZTRAKT: 2010-ben, amikor remény mutatkozott arra, hogy a hivatalba lépö konzervatív kormányzat változtatni fog a LEADER program eljárásrendjén, a hét magyar akciócsoport együttmüködésével létrejött NATURAMA Szövetség kiadott egy nyilatkozatot, amelyben összegezte a legfontosabb, változtatásra váró végrehajtási szabályokat (NATURAMA Szövetség 2010). A szerveződés bemutatását követö első fejezet címe: „Decentralizáció és autonómia”, ami jelzi a kívánatosnak tartott változtatás fó irányát, vagyis az akciócsoportok múködési és döntési autonómiájának növelését. Jelen tanulmányban két elemzési szempont, az autonómia és a helyi demokrácia mértéke, valamint a kettó interakciója szempontjából vesszük górcső alá a LEADER programot, feltárva, hogy ezek mennyiben kapcsolódnak a nemzeti szintü kormányzás változó irányaihoz, a decentralizációhoz és az újraközpontositáshoz.

A tanulmány elsö része a vidéktanulmányok (rural studies) és a kormányzáskutatás elméleti megközelítéseit összegzi a helyi demokrácia és autonómia LEADER programban való manifesztációjára fókuszálva. A legtöbb szerzö úgy tekint a LEADER-re, mint a helyi demokrácia erösitését, a részvételi demokrácia mélyitését eredményező vidékfejlesztési programra. Ezt a képet árnyalja, hogy a hivatkozott tanulmányok szerzőinek többségi véleménye szerint a 'LEADER-demokrácia' társadalmi hatóköre viszonylag szük, a részvétel a vidéki társadalom módosabb csoportjaira szoritkozik, amelyben két mechanizmus játszik szerepet: az egyik a Helyi Vidékfejlesztési Stratégia szükitö-szürő hatása, amely célkitüzései és fejlesztési prioritásai mentén határozza meg a programban érdekeltek körét, a másik az eljárásrendek bonyolultsága.

A tanulmány empirikus hátterét egy-egy, a decentralizáció (és újraközpontositás) komplex tapasztalatait bemutató esettanulmány nyújtja, az egyik egy angol (Northumberland Uplands), a másik egy magyar (Éltetö Balaton-felvidékért) akciócsoportról készült 2018-2019-ben a RELOCAL projekt keretében és támogatásával. A LEADER két ciklusát leíró esettanulmányok másodelemzése azt a nem várt eredményt hozta, hogy az angol intézményi környezet és kormányzási hagyomány enged több fölülról kezdeményezett beavatkozást és eredményez korlátozottabb helyi autonómiát, nem pedig a vizsgált ciklusokban az átalakulás számos problémájával küzdo", újracentralizált magyar gyakorlat.

\section{Introduction}

In this paper we explore the concept of autonomy as it relates to the EU's LEADER rural development programme, in two countries with complex recent histories and trajectories in terms of devolution of governance to lower levels and local autonomy. A conceptual review finds that the concept of autonomy in local governance, although it may to some extent need to be traded off against other policy goals (including equal development across regions), has the potential to deepen local democracy, through widening participation as a procedural aspect of spatial justice. In the empirical part of the paper, the democratic implications of autonomy are explored through two case study LEADER actions, both conducted within the framework of RELOCAL, a large-scale 
H2020 project, ${ }^{2}$ in 2018-2019: one in England ${ }^{3}$ and one in Hungary. The published case studies from the project range across two LEADER iterations (2007-2013, denoted as Phase 1 in this article, and 2014-2020, denoted as Phase 2); here the case-study material has undergone a secondary analysis with a focus on governance issues and autonomy.

After this introduction, where we outline the paper and present the main points of the LEADER programme and its development over the last three decades, the paper has six further main sections. In the second section the analytical framework is introduced, linking the concepts of governance, decentralization, democracy and autonomy with the LEADER approach, particularly with regard to the recent transition in European policy toward a more participatory form of democracy, which frequently but not automatically goes hand in hand with decentralization of governance (of which LEADER is an example). The section then moves on to focus on literature that critiques autonomy and participative democracy in LEADER, taking into consideration their outcomes on spatial justice. The third section moves on from the LEADER literature to consider how LEADER actions are framed by the governance context in our case study nations, generating two main questions for this paper's secondary analysis of the case studies. The methodology of the original case studies and their secondary analysis are explained in the fourth section, while the fifth presents the empirical findings and section six discusses these findings in relation to the two framing research questions. The paper concludes by weighing up the democratic implications of the erosion of LEADER autonomy and proposing measures for safeguarding its autonomy in future iterations.

\section{An outline of the LEADER programme}

LEADER is now in its thirtieth year of operation, having been introduced in Europe in 1991. At the highest, EU, level LEADER evolved from an experimental phase, focused solely on deprived rural areas, and targeted at identifying and building on local economic strengths with the aim of reducing rural-urban disparities. Over time, the EU's framing of LEADER developed a greater focus on intra-regional equity, creating internal spatial justice through addressing the inclusion of marginalized groups (ENRD 2016; Shucksmith, Brooks, Madanipour 2021). At an administrative level it has moved from being an independent, smallscale funding stream of $£ 1.2$ billion in LEADER I, shared between 217 schemes; to integration as a delivery option within a major EU funding programme (Pillar 2 of CAP), at a value of $£ 9.8$ billion, implemented by over 2,650 schemes as part of overall EU rural development policy (Atterton et al. 2020).

The seven principles, ${ }^{4}$ set out by the European Commission, give the LEADER approach the capacity to deliver bottom-up rural development for an enlarged Union. LEADER has both a horizontal, networked aspect and an aspect of vertical 
integration in this sense it is both bottom-up and top-down. Shucksmith, Brooks, and Madanipour (2021) argue that, while Local Development Strategies were negotiated with and approved by the European Commission in LEADER I, subsequently the scheme has become ever more subject to national and subnational oversight and control (Ray 1998; Hubbard \& Gorton 2011; Müller et al. 2020; Konečný et al. 2021, cited in Shucksmith, Brooks, Madanipour 2021, 323.), a process of appropriation observed in numerous European case studies. This is one of the key dimensions along which our case studies were analysed and compared.

\section{Analytical framework: main concepts and their relationship to LEADER}

This paper explores the LEADER programme as a form of local, decentralized governance. It might be assumed that the purpose of decentralized governance is to generate better spatial justice outcomes through mechanisms such as enhanced (more participative, deeper) democracy and greater local autonomy. The connection between these components - decentralization, democratic participation and autonomy - and their spatial justice outcomes is however neither direct nor automatic. The following subsections explore each conceptual component and their connection with the LEADER programme. Following this, the section goes on to consider critiques of democratic participation and autonomy in LEADER, in particular with regard to 'internal' and 'external' spatial justice outcomes.

\section{Governance and Decentralization}

Governance has been usefully defined as "the system of values, policies and institutions by which a society manages its economic, political and social affairs through interactions within and among the state, civil society and private sector" (Work 2002, 1.). Thus, decentralization of governance can be brought about not only through the public sector but through civil society and by privatization. In advanced capitalist countries, decentralization was driven by the so-called neoliberal turn of the last decades of the 20th century: this entails a reduced central state with competences devolved to lower levels, as well as more collaborative governance. In the UK and England, decentralization has been a particularly complex process, whereby an attempt to create English government regions lasted only from 1994 to 2010, but devolution of power to three of the country's four constituent nations has gathered pace since 1998; while in England, representing $84 \%$ of the UK's population, it has proceeded more slowly.

It is not only neoliberal ideology that can induce decentralization of the central state, but historical events can also trigger radical decentralization: this 
was the shared experience of a number of Central and Eastern European (hereinafter CEE) countries at the time of the fall of state socialism, deriving from authentic political demand on the part of municipalities for democratic control and autonomy (Devas, Delay 2006, 678.). The process of Europeanization also played a pivotal role in the creation of more decentralized multilevel government structures in CEE countries; Romania was cited as an example by Marquardt, Möllers, and Buchenrieder $(2012,5$.$) but, more generally, 'regionalization' of$ government was considered as an important condition for entering the EU across the region. However, as the Hungarian case illustrates, decentralization and even (a restricted) local autonomy might fade away as a consequence of a political turn (Pálné Kovács 2020, 46; Kákai 2020); and more generally in the CEE under the pressure of the efficiency argument (Loewen 2018).

LEADER, giving not only programme-forming, but grant-giving powers to self-defined rural areas, has sometimes been described as a form of decentralized governance (e.g., Siebert, Dosch cited in Furmankiewicz, Knieć, Atterton 2015, 136.). However, the relationship between LEADER and decentralization may be more complex. For example, Chardas $(2017,629$.) argues that realization of LEADER goals presupposes the existence of state apparatuses with decentralized competences and financial autonomy: this runs into problems in highly centralized states, such as the austerity-driven Greece of his case study.

\section{Autonomy}

Autonomy is a strongly normative term. As such, it can be viewed as 'ethical', a good to be desired for its own worth, representing freedom of choice and direction of development for groups of co-located people (Smith 1851). Conversely, it can be valued as 'expediential', a means to bring about more effective governance (Mill 1861; Erlingsson, Odelen 2017). Both reasons for valuing autonomy are likely to be relevant, but in different proportions depending on the context.

Multiple authors (cited in Johnson 2001, 521.) make the link between decentralized democracy and governance that is more responsive to local conditions and thus more effective. Fleurke and Willemse (2006) point out that while decentralization is often associated with autonomy, the connection is neither direct nor automatic. Autonomy may be the 'linking concept' between decentralization and positive outcomes: the central hypothesis of a recently published volume is that the "degree of decentralization and the level of local autonomy correlates positively with the level of development" (Silva 2020, 2.).

Autonomy is often considered to enhance and improve democratic institutions: Luckham et al. (cited in Johnson 2001, 523.) found that democratic institutions (elections, the independent judiciary, etc.) tend to be riven with elite bias, along lines of religion, class, sex and other social groupings, but contestation, self-determination and struggle can all contribute to the deepening of democracy 
and the development of more representative policies. A recent study suggests that level of autonomy of the local governance body may be the critical factor in democratic participation: Van Houwelingen (2018) found that at the small scale, local governance level, the level of autonomy has an impact on local participation, permitting the development of a responsive political system and thus encouraging people to take an active interest in local politics. The link between local autonomy and people's interest in participation was not, however, found by the authors to apply at the larger scale.

The association between LEADER and (local) autonomy is embodied in the first two LEADER principles": 'area-based Local Development Strategies' and 'bottom up elaboration and implementation of strategies' - particularly the latter.

In scrutinizing LEADER LAG autonomy, we adopt the approach of Ladner, Keuffer, and Baldersheim (2015) as already adapted for the objectives of the wider RELOCAL project by Blondel and Evrard (2020) who made the first attempts to link the concept of local autonomy to spatial justice. Following Ladner, Keuffer, and Baldersheim (2015) Blondel and Evrard used the definition unaltered from Clark, who in a seminal article identified two primary principles of local autonomy: the power of initiation and the power of immunity (Clark 1984). Initiation according to Clark means "the actions of local governments in carrying out their rightful duties" whilst immunity expresses "the powers of localities to act without fear of the oversight of higher tiers of the state. (...)" (Clark 1984, 198.). Translating the language of Clark to the LEADER context, as the powers of LEADER LAGs, 'to initiate', or in the words of Blondel and Evrard "to accomplish tasks of local interest" $(2020,8$.) [their emphasis] covers the wide scope of the LAGs' rural development activity. Regarding the immunity of LEADER LAGs, which can be translated as the possibility "to act, without oversight by higher levels for the local interest" (Blondel, Evrard 2020, 8.) [their emphasis], the literature provides ample examples as we will see later in this paper.

\section{Participatory democracy}

As noted by Muller, Sutter, and Wohlgemuth (2020), widespread attention has been devoted to the general shift towards participatory governance as part of the transformation of the welfare state in Western democracies (Cruikshank 1999; Tooke 2003; Blakeley 2010; Rosol 2013; Rosol 2014, cited in Muller, Sutter, Wohlgemuth 2020,223.). The participatory approach is one of two main schools of thought with regard to democracy (literally 'rule by the people') and is generally contrasted with representative democracy, where rule is delegated to elected representatives (Parry, Moyser 1994).

By contrast, in participatory democracy, the process of taking part is integral to democracy, although there are differing views of what forms this should take: "Deliberation, the search for consensus, the desire to encourage the 
reticent or the less privileged to have their say, the educative effects of involvement - all are valued in different ways" (Parry, Moyser 1994, 388.). For the participatory school, while elected representatives have a role to play, the decisive test of a democracy is its capacity to encourage its population to play an active role in its own government; various tools and techniques of participatory governance are deployed (from plebiscites and petitions to consultation and participatory budgeting) to enable the population to steer governance decisions at any scale from macro to micro; while decentralization of government functions allows for more direct participation and a closer relationship between governments and governed.

The nature of the democratic process embodied in the LEADER approach and whether it strengthens local democracy or not is one of the key questions of a volume by Granberg, Andersson and Kovách (2015). In most national contexts elaborated in this collection of articles, LEADER appears as a promoter of local democracy, however, attention is called by the editors to democratic deficit. In the same way, "networks of governance, such as those derived from LEADER, are sometimes seen as undemocratic, due to the delegation of decision-making power to public, private and civic stakeholders" (Granberg, Andersson, Kovách 2015,10 .). Most of the articles in the volume reflect on the distinction made by March and Olsen (1989) between aggregative and integrative versions of democracy. The former is based on the traditional institutions of representative democracy, the latter is comparable to aspects of participatory democracy as outlined above, being "built on the idea of deliberation towards an identification of the common good. From this stance, the role of representatives is to promote deliberation, which makes citizen participation crucial. (...) Contrary to the aggregative version, democracy is not viewed as a power struggle between different individuals or factions but rather as a forum for deliberations regarding the common good" (Thuesen 2015, 82.). LEADER is considered by most of the book's contributors as closely related to the integrative version of democracy. Nevertheless, paradoxically, if the character of LEADER democracy is assessed through the seven criteria set in an earlier paper by Andersson and Kovách (2010), a picture of a more "hybrid form of democracy" unfolds from the analyses that combines aspects of both aggregative and integrative styles, both in the case of national models of LEADER (Munck af Rosenschöld, Löyhkö 2015, 17.; Osti 2018, 153-154.), and in EU Council LEADER regulations (European Commission 2006; ENRD 2016; Thuesen 2015, 86.).

The degree of hybridity in LEADER democratic structure noted by Andersson and Kovách may vary between countries and between LEADER actions in each country. In their ethnographic study of two LEADER regions in Germany, Muller, Sutter, and Wohlgemuth (2020), observe that the requirement for local participation in the LEADER programme, alongside the lack of higher-level prescription about what forms that participation should take, opens the way for 
great variety of forms and levels of participation. They trace multiple negotiations and performances of participation in their case study actions - that can also include a rejection of calls to participate - and emphasize that such enactments of participation are not only features of LAG Boards, but also of LEADER project development and implementation.

\section{Critiques of democratic participation and autonomy in LEADER}

LEADER has usually been mentioned as a positive example of the EU rural policy palette with at worst certain problematic aspects. More recently, however, it has been subject to harsher critiques, focusing on possible negative outcomes of increased local participation and autonomy for parity between subregions and internal spatial justice. These studies criticize the meagre impact on social and/ or territorial injustice of either LEADER or similar decentralized development programmes, which they assign to the negative impact of neoliberal governance patterns. They question if participation and a larger scope of local autonomy in the absence of adequate resources will result in empowerment due to development. Zamfir argues, for example in his article on the Mara Natur LAG ${ }^{5}$ in Romania (Zamfir 2020), that in the prevailing context of intricate procedures, dearth of civil society organizations and insufficient funding for basic infrastructure, LEADER serves first and foremost as a pedagogical exercize in uneven development. In this vein, LEADER actors' newly inculcated civic skills become factors in exacerbating inequalities between places.

Similar harsh criticism by Husu and Kumpulainen (2019) was raized in relation to the 'creation of new moral actors' as an outcome of aspirations in neoliberal policy to 'empower' local communities through (among other things) participation. The critical discourse around the neoliberal (Finnish) rural development paradigm argues that "community development is not about transferring more power to local people, but rather about withdrawing government resources from communities" (Husu, Kumpulainen 2019, 895.). The authors' critical judgement resonates with Peck and Tickell's (2002) process-based analysis according to which through neoliberalization "local institutions and actors were being given responsibility without power" (Peck, Tickell 2002, 386.). The concept that provides a chance of mitigating the shortcomings of neoliberalization is Shucksmith's 'disintegrated rural development'. Shucksmith argues that the state can contribute to empowering local communities if it is capable of "becoming a catalyst for local action, mobilising less powerful actors and becoming an agent for change", as the example of Scottish community-based land reform indicates (Shucksmith 2010, 10.).

Almost the converse of a disintegrated rural development approach was reported by Chardas as taking place in austerity-driven Greece, where austerity measures imposed by the Greek Government percolated down through a highly 
centralized and corruption-ridden state to local actors. According to Chardas, declining financial resources in Greece were also coupled with corrupttion, which undermined the organizational autonomy of the LAGs. "The political manipulation of the projects that are to be implemented is a constant feature of the project selection process in the LEADER programmes. All the mayors and elected members of regional councils are attempting to intervene and promote investment programmes of their political friends" (Chardas 2017, 630., 639.).

What was essentially government intervention over LAG autonomy was reported by one of our case studies from the post-crisis UK, to be introduced in more detail in the empirical section. In this case, local development strategies were overridden by the responsible government ministry, imposing a mandatory minimum limit (70\%) of LEADER spending on job creation (Shucksmith, Brooks, Madanipour 2021, 10.). This government action is less surprising if one takes into consideration the UK's poor reputation regarding the 'immunity' of local government bodies. According to Ladner, Keuffer, and Baldersheim's Self-Rule Index $(2015,47$.) the UK figured in the group of lowest-scoring countries, with a value of 11.74, compared to which only Ireland scored worse among the EU's advanced capitalist countries (10.47). Of the 39 European countries reviewed, 29 were placed ahead of the UK.

Navarro Cejudo, and Maroto (2016) implemented a comparative survey among LAG managers in Wales and Andalusia which is highly relevant from the point of view of governance issues. Managers were asked among other things about their LAG's degree of autonomy, with the following disillusioning results: "LAGs have often been controlled by mayors and political representatives of the local and regional public sector, and this has resulted in the RDPs being used to promote political patronage, with political and economic leaders taking decisions over objectives (...)" (Navarro, Cejudo, Maroto 2016, 283.). At this point the conclusion begins to consolidate that the Greek case described by Chardas may not be that far from the mainstream.

Numerous less radical critiques of the impact of the LEADER Programme on 'internal' spatial justice diagnosed that the LEADER approach fails to reach vulnerable layers of rural communities. Those who are already well resourced, skilled and networked can access LEADER programmes and cope with the demands of the grant applications process, whereas lower skilled, more isolated actors with less capital behind them may struggle to engage and if engaged, to win grants (Shucksmith 2000; Ellis 2001). Furthermore, due to various factors including 'self-selection' of participants, and the lower visibility and more fragmented geographies of minorities in rural areas, it cannot be assumed that more democratic governance arizes from increased participation without greater scrutiny (Muller, Sutter, Wohlgemuth 2020). Navarro, Cejudo, and Maroto (2016) adduce a long list of authors who found that the LEADER and/or endogenous development approach can reinforce existing power structures and marginalize the poor. 
The latter article also calls attention to the specificities of the CEE context owing to a weak presence of interest groups in rural areas in general, and civil society organizations in particular, as a legacy of the socialist past, aggravated by rural outflow, which had been triggered by transition from state socialism. This was a common finding for Furmankiewicz et al. (2010) in the Polish context, Macken-Walsh and Curtin (2013) in the Lithuanian context and Marquardt, Möllers, and Buchenrieder (2012) in the Romanian context. And, as we have seen in Navarro, Cejudo, and Maroto's comparison of Wales and Andalusia, the public sector dominance in LEADER LAGs and the strong influence of the power elite are not specific to the CEE countries (Esparcia, Escribano, Serrano 2015, 33., 39.; Navarro, Cejudo, Maroto 2016, 283.).

Therefore, the question emerges of whose democracy is enhanced by the participation and increased democratization of local governance that LEADER might provide. The answer is: those who are active members of the local community (Thuesen 2010) and are already included in the LAG, which might even be closed, excluding non-LAG members from the scheme's grant distribution. Benefiting the non-vulnerable social layers might be the outcome of filtering mechanisms due to themes of development (measures of the Local Development Strategies), given that enterprise in either agriculture or off-farm activities generally requires access to resources and procedural difficulties are triggered by complexity of the application process.

\section{Governance of LEADER in the case study nations and research questions}

In this section, we move on from the LEADER literature to consider how autonomy and democratic participation, in LEADER and more generally, are framed by the governance context in our case study nations. This generates two main questions for this paper's secondary analysis of the case studies.

\section{Organization of government and LEADER}

In spite of devolving many powers to three of its four constituent nations in the 1990s, and implementing a range of devolved powers to cities, city-regions and neighbourhoods since 2009, as noted earlier, the UK is known to be one of the most centralized developed countries in the OECD, if not the world (Game 2016, 5.). Additionally, the UK, and England in particular, have "by far the largest scale of local government in Europe": translating to a mean population in excess of 160,000 and an average area of $400 \mathrm{~km}^{2}$ for each of England's 326 local government districts (Game 2016, 3.). Large-scale local authorities are double edged in terms of autonomy: they may be more efficient and competent, weighty institutions, operating on a scale that gives them major influence and power in a locality, but at 
the same time "the smaller the number of local authorities, the greater is the ability of central government to control the finances, direct the policies, and monitor the performance of local authorities individually, as well as collectively" (Game 2016, 5.).

In Hungary, local government is on a much smaller scale: the average population of Hungary's municipalities is 3,200 and over half of the municipalities (equivalent of England's 'local authorities') have a population below 1,000 (Wetzel, Papp cited in Rodríguez-Pose, Krøijer 2009, 414.). While Hungary pioneered reforms in the legal and institutional framework required for decentralization of powers (Dabla-Norris 2006), many of these were subsequently weakened or rescinded (Kákai 2020).

There are further substantial differences between the two countries, as far as the institutional environment at the local level is concerned. These are partially related to divergent multi-level governance structures and related management patterns. In Hungary, the LEADER Programme has always been governed from the centre; in England, implementation was still regionalized at the beginning of the 2007-2013 LEADER iteration, up to 2010, when the regional level in England began to be dismantled following a sharp political turn to the right. The political turn in both countries paradoxically brought about similar changes in multi-level governance: the beginning of significant recentralization by, among other means, abolishing NUTS-2 regions (in Hungary LAU-1 microregions as well). Moreover, in Hungary, recentralization had an extreme and multi-pronged impact on NUTS-3 level (county) governance and municipal governance through renationalization of education, health and social care services from 2012 onwards (Pálné Kovács 2020, 2021). Further differences of institutional environment for implementing the LEADER Programme can be illustrated by the role of local authorities in the UK assuming administrative and supporting functions (host body, accountable body) for LAGs. Such an institutionalized pattern of embedding LAGs into the realm (and services) of local authorities was unknown in Hungary in the two examined iterations of LEADER.

Continuing with the LEADER Programme as it matured through its successive phases, the advantage of the UK was immense at the beginning of the 2007-2013 cycle, when, compared to the previous period, the number of LAGs increased significantly, rising in England from 25 to 65 LAGS (Brown, Carnegie Trust 2010), covering 52\% of England's rural population (Annibal et al. 2013). The UK had taken part in all iterations of LEADER since its introduction in 1991, while Hungary only joined the European Union in 2004. However, a so-called experimental LEADER Programme was already launched there in 2001 by the Rural Development Department of the Ministry for Agricultural and Rural Development. This was followed by LEADER Plus ${ }^{6}$ after EU accession in 2004, still as a pilot phase, but with the opportunity of learning and experimenting now provided for many more LAGs (70). It was with the 2007-2013 cycle that LEADER implementation in Hungary entered a more-or-less established phase. Unlike in 
the UK, Hungarian policy makers decided to implement LEADER not only as a separate axis (Axis 4) of the Rural Development Programme (hereinafter RDP) but also as a crosscutting instrument in the delivery of four of the $\operatorname{six}^{7}$ measures of Axis 3. This is the period when the programme was extended to the entire rural territory of the country 8 - which did not happen in the UK until the most recent programming period.

\section{The broader EU rural policy context}

The main goals to be achieved by the EU Rural Development Programme were changed rather significantly in the 2014-2020 iteration. New priorities emerged, such as Priority $6^{9}$ addressing poverty reduction. A greater sensitivity towards social issues, however, mostly remained at the level of rhetoric rather than reality: because social inclusion was to be achieved as an overall impact of economic and ICT development, the scope of Local Development Strategies (hereinafter LDS) did not show much difference from those of earlier iterations in the Hungarian case, while in the English case the top-down imposition of primarily economic priorities on LDSs by central government would have weakened or removed any social priorities generated at the local level. Therefore, the relevance of LEADER concerning spatial justice remained rather limited in the Hungary case and was reduced in the England one. The new EU framework for rural policy provided more flexibility for national level policymakers than before, which was used to a different degree in member states. In MansfeldSüdharz (East Germany), for example, 14\% of the RDP's budget was allocated to LEADER (Dax, Machold, Bauchinger 2020, 34.), whilst in the two countries under investigation, the allocation was limited to the mandatory minimum of $5 \%$ and in neither country was the most important innovation of the programming cycle, namely multi-funded CLLD, adopted. Contrary to the UK, where the financial support for LEADER remained more or less the same but was distributed among a much greater number of LAGs in the 2014-2020 period, in Hungary, the implementation of the RDP changed drastically. Namely, the management of the formerly decentralized Axis 3 measures mentioned in note 7 was recentralized in the 2014-2020 cycle, resulting in a sharp drop to about one quarter of the previous level of financial resources managed by the LAG agencies. Since then, the poorly funded LEADER measure itself remained the sole measure implemented in a decentralized manner by LAGs, which induced significant erosion of human capacities engaged in rural development across rural Hungary.

Based on the theoretical background of our key concepts outlined in the second section and the complex recent histories and trajectories of LEADER governance in the case study countries noted above, we are now in a position to sketch two key questions with regard to LEADER governance and its implications for programme impacts, as follows: 
1. What role does higher-level governance play in determining LAGs autonomy, democratic participation, development and justice outcomes over the last two LEADER phases?

2. What is the impact of national-level recentralization on the governance of LEADER programmes over the case study period?

With these two questions in mind, we now move on to describe our case study methodology.

\section{Methodology}

The comparison of the two LEADER actions with regard to degree and contexts of LAG autonomy and local democracy was achieved through a secondary interpretation of the original case studies (Kovács, Nemes 2019; Brooks, Shucksmith, Madanipour 2019). The framework for this interpretation was proposed by one of the case study authors (Kovács), followed up by virtual workshops which took place in 2021. The framework for the analysis was generated by adapting three prior studies on local autonomy: Clark (1984), who established a theory of local autonomy in 1984; Ladner, Keuffer, and Baldersheim (2015) who reinvented Clark more than 25 years later and broadened the dimensions of local autonomy through which their Local Autonomy Index was developed; and last but not least, Blondel and Evrard (2020), who adapted Ladner, Keuffer, and Baldersheim's dimensions and connected them with spatial justicethe key to the conceptual foundation of the RELOCAL project.

Based on the aforementioned, strongly-connected concepts of local autonomy, which build on one another from Clark, through Ladner, Keuffer, and Baldersheim, to Blondel and Evrard, we have developed aspects of comparison of the two LEADER cases in such a way that these aspects should help in responding to the two main research questions of our study. These aspects are introduced in the table below.

The comparison was facilitated by the harmonized content of the original case studies, which were structured in line with the Case Study Manual developed by Weck et al. (2020) within the RELOCAL project. ${ }^{10}$

For the purposes of this paper, we can summarize the method as combining desk study and interviews organized around the study's main themes (including governance, participation and autonomy) and including set categories of stakeholders, taking place from 2018-2019. Stakeholders were recruited from both Phases of the LAG, and ranged across governance levels (LAG, Local Government, Regional agencies, National Government). A host of other resources supplemented interview data including LAG, Local, Regional and national bodies' documentation, local media reports, participant observation of LAG meetings (in the Hungary case) and non-participant observation in the UK case. Stakeholder 
involvement and consultation was a core feature of the case study method and process, with a consultation meeting preceding the interviews and following them, to verify the results with stakeholders.

Table 1: Aspects of comparative analysis of the two LEADER actions

A két LEADER-akciójellegzetességeinek összehasonlitó elemzése

\begin{tabular}{|c|c|}
\hline Analytical aspects & Addressed governance issues \\
\hline \multicolumn{2}{|r|}{ Aspects of investigating LAG autonomy } \\
\hline $\begin{array}{l}\text { Strength of 'initiation' at the } \\
\text { local level }\end{array}$ & $\begin{array}{l}\text { "Right and capacity to act" (Blondel, Evrard, 23.); LEADER as } \\
\text { part of RDP (financial support, knowledge-transition, plan- } \\
\text { ning and implementing rules, local capacities) }\end{array}$ \\
\hline Degree of 'immunity' & $\begin{array}{l}\text { "The possibility for a local authority to act, without oversight by } \\
\text { higher levels, for the local interest, and in particular for the locality } \\
\text { and its population" (Blondel, Evrard, 23.) } \\
\text { Degree of autonomy in developing LDS, organizational auton- } \\
\text { omy, modes of control, direct and indirect, incidents of top- } \\
\text { down interventions }\end{array}$ \\
\hline \multirow{2}{*}{$\begin{array}{l}\text { Scope of participation - repre- } \\
\text { sentation of social layers of the } \\
\text { LAG area }\end{array}$} & "Government by the people" (Blondel, Evrard, 23.) \\
\hline & $\begin{array}{l}\text { The role of participation within the development process } \\
\text { from the first steps of 'initiation' (establishing the area and } \\
\text { recruiting LAG members), through planning, to evaluation. } \\
\text { Representation of various social/ethnic groups of the LAG } \\
\text { area within the decision taking bodies. }\end{array}$ \\
\hline $\begin{array}{l}\text { Depth and quality of participa- } \\
\text { tion = the extent to which } \\
\text { place knowledge is absorbed }\end{array}$ & $\begin{array}{l}\text { Whether "vernacular / local/place knowledge is an integral part of } \\
\text { the development process" (Blondel, Evrard, 53.) }\end{array}$ \\
\hline
\end{tabular}

Aspects of identifying social and spatial impacts of local autonomy

Presence and degree of social Whether clear social targets can be identified in the LDS, if

targeting of the LDS and how the targeted social groups were benefitted through implementation of the LDS (including a higher level of integration into the local societies); impact on social (sociospatial) disadvantages

Presence and degree of spatial Whether clear spatial targets can be identified in the LDS, if targeting of the LDS and how spatial disadvantages were reduced through implementation of the LDS (including a higher level of integration into local communities); impact on social (socio-spatial) disadvantages

Degree of empowerment If and how the empowerment of rural communities occurred reached through the action as a positive impact of the LEADER action

Source: Authors' construction 


\section{Two variations on one policy concept: the LEADER Programme in the UK and in Hungary 2007-2020}

\section{The local contexts}

The size and territorial coverage of the LAGs were by and large similar in the two cases, representing areas with resident populations of 43,000 (Hungary) and 33,000 - 55,000 (UK, expanding between Phase 1 and Phase 2). It is characteristic of LEADER that the LAG catchment area will have been evolved specifically for the bid to the programme, and it may not have any other governance or administrative profile outside of the LAG action. Therefore, emerging shared identity is indicative of a successful community-building process implemented throughout the idiosyncratic LAG history. It is probably not by chance that positive connotations concerning the LAG community and a definite, newlyevolved common identity seem to be stronger in the Balaton Uplands case, where the LAG catchment area was built through a series of negotiations by the local actors in 2007 than in the NULAG case, where the LAG area was delineated by the Regional Development Agency, One North East (ONE NE), in 2007 and expanded in Phase 2 due to LEADER rule changes allowing inclusion of larger rural towns (Shucksmith, Brooks, Madanipour 2021).

The first NULAG catchment area was separated from the more prosperous and accessible coastal area of the former North Northumberland LAG, consisting of remote uplands, which are dominated by low-income upland farms, forestry and military ranges, and with an economy characterized by SMEs and microbusinesses. ONE NE was also responsible for bringing together the team of uplands residents who were behind the first NULAG LDS, which represented the bid to central government for the LEADER grant. In its second and final period when it was hosted by the Local Authority, Northumberland County Council, this LAG expanded its boundaries to embrace several peripheral market towns.

The composition of the LAG Board was balanced during Phase 1 in both cases, although different in terms of tripartite representation of sectors: the nine members of the Board of the Balaton Uplands LAG represented three sectors, public (three mayors), business (four entrepreneurs) and two NGOs reflecting the Hungarian norm, where ordinary citizens are represented by civic organizations. The number of LAG General Assembly members more than doubled since establishment due largely to a popular Quality Mark network, a project developed by the LAG through a co-operative initiative attracting mainly small business holders to the LAG. According to the Balaton Uplands LAG's homepage (https://eltetobalatonfelvidek.hu/egyesuleti-tagok/), among the 272 General Assembly members the public sphere was represented by 56 localities, the number of NGOs represented was 58 and there were 158 entrepreneurs, a composition which clearly expressed the 'character' of the LAG. In the case of 
NULAG, there was no General Assembly, and the LAG was effectively the Board of Members plus the Programme Officer and support staff from the Local Authority, ranging between 14 and 26 people, with considerable turn-over in membership, particularly during the 2014-2020 iteration. In the first iteration, besides the Programme Officer and support staff from Northumberland County council, there were three mainly public sector, five mainly NGO and 15 mainly business (mainly agri-business and land management) members - in practice many members' biographies show current affiliations to more than one sector. Notably, there was careful selection of members by location in the vast Uplands catchment area, so the main settlements and districts of the NULAG territory were evenly covered. By the end of the second iteration, the Board had reduced to 12 members (excluding the Project officer and council support staff), with five public sector, three NGO and four business members with a residential bias towards the south and southeast of the NULAG catchment area. There was little continuity from the previous iteration: only one member of the most recent Board was also part of the Board when the LAG was set up in 2007.

The comparison of the cases will continue in the sections below through three themes, closely related to the degree of autonomy: (i) participation, as a specific tool to garner local knowledge within the process of constructing a LDS, to recruit LAG members and grant applicants subsequently; and (ii-iii) the powers of LAGs concerning 'initiation' and 'immunity'.

\section{Participation at LAG level}

The comparison of the cases shows rather significant differences regarding the participatory nature of the LDS process: three years after EU accession, a great deal of enthusiasm for the programme still prevailed in Hungary (see also Kovács 2018), and thus mobilization of the population was relatively unproblematic in general, and in the Balaton Uplands LAG area in particular, where, as mentioned above, the LAG area was established through negotiations of the locals, experience had been built up with LEADER Plus, and an extremely hardworking staff was recruited with 10-12 people during the peak of Phase 1. The three offices of LAG Agency were distributed evenly across the LAG area, thus making its services more accessible to the population. The Agency was set up and staffed by people representing a variety of expertise from lay through different kinds of expert knowledge to vernacular knowledge, which is "place based but crucially nourished by outside sources and agents" (Lowe et al., 2019, 28.). By the end of Phase 1, two of the LAG offices had closed down, the personnel contracted from ten to three people, the chief manager left, and the staff continued with one experienced and two young, inexperienced recruits in Phase 2. According to the midterm evaluation of the LEADER Programme, this reduction in human capital was common 
across LAG offices in Hungary and caused a significant shrinkage of capacities for animation (Nemes, Magócs 2020).

In the NULAG case, participatory strategy building was hampered to some extent by the England policy of mainly using the unpaid contributions of voluntary members for LAG activities, entailing a low number of paid staff (two to three full-time paid employees in Phase 1 and one person, supported by a dedicated administrator at the Local Authority in Phase 2). The catchment's accessibility issues may also have played a part - the Northumberland Uplands is a very large, hilly territory of some $3,232 \mathrm{~km}^{2}$ with some poor quality internal road systems, truncated at its northern edge by the border with Scotland with its very disparate governance and political traditions. Furthermore, the initial catchment was extended in the 2014-2020 cycle and place identity was disturbed by amalgamations of local governments in 2009 and changes of electoral ward boundaries in 2013. On the other hand, largely due to the part-time retention of an exemplary programme officer between the penultimate and last LEADER phase in England, wide-reaching and in-depth consultation was undertaken during the development of the 2014-2020 Local Development Strategy. But overall, as an ongoing, rather than one-off activity, in line with what an earlier comparative research of the British and Finnish LEADER Programmes revealed, "participation in the British LEADER system was limited. Often the whole question was regarded as irrelevant by referring to either the low interest of local citizens to participate or the usefulness of doing so in the first place" (Munck af Rosenschöld, Löyhkö 2015, 23.).

\section{The scale of autonomy; powers of initiation and immunity}

Power of initiation can be interpreted after Clark as "the actions of [LAGS] in carrying out their rightful duties" (Clark 1984, 198.), thus the notion of initiation in case of the LEADER Programme covers development activity over the entire duration of the programme cycle at the local level, and it intertwines with participation from the appraisal phase of the LDS onwards. This is the phase when overall development targets are set up, local knowledge accessed by animation is channelled and built into priorities and measures. Depth of local knowledge is to some extent a corollary of the extent of local participation as described in the previous section, as it impacts the quality of the LDS data, which provides not only a firm and place-shaped foundation to creating priorities for the LDS, but also helps implement the strategy through the established network of contacts.

'Powers of initiation' for Local Action Groups under this broader interpretation mainly depend on three factors: (i) the LDS process; (ii) the resources available; (iii) and the capabilities of the potential applicants. With regard to the LDS process, the participative nature of the strategy-building and grant application process 
has been detailed above. Concerning resources - the amount of money available for animation and project development - in both cases, these declined in between the first and second iterations as mentioned above.

Freedom of LAGS from oversight and interference from higher governance levels, called 'immunity' by Clark (1984), depends on a number of factors, of which there is considerable overlap with powers of 'initiation'. It can be seen in Table $2 \mathrm{a}$ below that in the seven dimensions of autonomy adapted to the context of LEADER after Ladner, Keuffer, and Baldersheim (2015), those relating to immunity from interference (such as 3,5 and 6) remained unchanged or worsened between the two phases.

\section{Changes in LAG autonomy over time}

Table 2a below is based on a remote consultation followed by a workshop that took place between the case study research partners in 2021, attempting to categorize the ways in which autonomy has changed in each case study between the two most recent LEADER iterations.

This admittedly broad and consensual, rather than formal and operationalized, comparison of the degree of autonomy of the investigated LAGs ended up with a rather surprising result, namely, that in the British context, LAGs came to operate with lower degree of autonomy than in Hungary. The lack of deliberation between the central and local (LAG) levels is expressed by a 'does not apply' label regarding influence pertaining from the bottom to the top, while the degree of autonomy worsened in four dimensions in England, in three in the Hungarian case.

To highlight bottlenecks of autonomy in the cases of the two LEADER LAGS, some further explanation is needed:

- Independence in developing the LDS was in the power of the LAG in both cases, but independent implementation was not possible in Phase 2 of NULAG, when it fell under the control of central government, who overruled the existing LAG-defined LDS and restricted the eligible types of projects and funding, in line with government measures applied to the LEADER scheme in England as part of measures to combat the financial crisis;

- A degree of bureaucracy in the scheme administration was imposed by the multiple levels of governance of the LEADER Programme, from the $\mathrm{EU}$, down to national, regional and local government levels.

- A critical factor is the level of bureaucratic control, exercized by all levels of government, which was highly prohibitive in both cases;

- also, whether the LAGs can develop and implement their own projects, which was possible in Phase 1 in both cases but unavailable in the second. 
Table 2a: Estimated scores by degree of dimensions of LAG autonomy Changes from Phase 1 (2007-13) to Phase 2 (2014-2020)

A Helyi Akciócsoportok autonómiájának mértéke az autonómia dimenziói szerint Eltérések az 1. fázis (2007-2013) és a 2. fázis (2014-2020) között

\begin{tabular}{ll}
\hline NULAG & Balaton Uplands LAG \\
\hline
\end{tabular}

1. Legal autonomy: the formal statutes of LAGs and the modalities of their legal protection;

Degree: Fair, unchanged

Degree: Fair, unchanged

2. Policy-making discretion: the general distribution of competencies and the effective decision-making powers attributed to LAGs

Degree: Fairly limited, unchanged Degree: Fairly limited, improved

3. Scope: the range of topics, scope of development for the LAG and agencies (Multi-fund schemes, other modes of co-operation)

Degree: Strongly limited, worsened Degree: Fair, unchanged

4. Financial autonomy (of the LAG agency): the financial resources available for LAGs for operating their agencies and their ability to decide freely on the use of their resources

Degree: Fairly limited, worsened Degree: Limited, worsened

5. Organizational autonomy: the free territorial scope of organization, free choice of organizational form and modes of co-operation

Degree: Limited, worsened

Degree: Limited, worsened

6. Non-interference (='immunity'): the extent to which LAGs are free from external interventions (from 'above')

Degree: Strongly limited, worsened

Degree: Fairly limited, unchanged

7. Access: the degree of influence of LAGs on policy decisions and taken by higher levels of government; smooth governance provided by the institutional environment.

Does not apply

Does not apply (worsened)

Source: Authors' construction

Table 2b: A summary of category frequencies (changes in autonomy) between the two case studies Kategóriaváltások (az autonómia mértékében bekövetkezett változások) a két esettanulmányban

\begin{tabular}{lcc}
\hline \multicolumn{1}{c}{ Scores } & NULAG & Balaton Uplands LAG \\
\hline Does not apply & 1 & 1 \\
Strongly limited & 2 & 0 \\
Limited & 1 & 2 \\
Fairly limited & 2 & 2 \\
Fair & 1 & 1 \\
\hline
\end{tabular}

Source: Authors' construction 
As commonalities, it was revealed that both cases were subjected to long delays in implementation due to deficiencies in the administrative capacity of (or between) higher levels; both cases also experienced delays in MA (Managing Body in the England case) decisions, the issuance of guidance or electronic tools/ platforms for uploading applications, and so on.

Other (selected) contextual factors:

- the policy context: if the LEADER programme is supported by the policies of the national governments; this was broadly the case at Phase 1 in both cases but had declined considerably during successive governments from 2010 onwards;

- the governing culture: meaning the degree of local autonomy expressed by Local Autonomy Index (LAI) of Ladner, Keuffer, and Baldersheim is very low in the UK/England, and has declined greatly since 2010 in Hungary (Ladner, Keuffer, Baldersheim 2015, 47.);

- the procedural context:

- During Phase 1 in the Hungarian context, central management, delays and bureaucratic control were severally hindering procedures (Csurgó, Kovách 2015; Finta 2020; Kovács 2018). Bureaucratic control was also to some extent a problem in the British context but become more acute towards the end of the first programming period after the role taken by the dissolved regional level of governance was assumed by the Rural Payments Agency. In Hungary, the control had already softened to some extent by the end of the 2007-2013 cycle, but delays were even longer during Phase 2; England also saw delays of between 1 and 2 years in the second phase.

- Guarantees of (or lack of) fair procedures: stability and continuity in staffing and maintenance of responsive contact with the LAG from higher government levels - in England this was affected by austerity staffing cuts to various governance bodies, in Hungary the 'interiteration gap' financial crisis eroded the human capital, quality of communications and trust;

- Legal guarantees to contest or otherwise appeal government body decisions have been available in both iterations in both countries.

\section{Discussion}

The comparison of the two cases for LEADER actions implemented in the UK and Hungary revealed that modes of implementation are significantly influenced by institutional and policy contexts determined at the national level. This is also the case for the LAGs' level of autonomy. In responding to our first research question, the influence of these governance factors on LAG autonomy are weighed against 
local and territorial factors and their spatial justice outcomes considered. In answering the second question, the issue of whether the context for LEADER in our case study countries since 2007 has been one of neoliberalization or its opposite, is explored. ${ }^{11}$

With regard to our first research question: "What role does higher-level governance play in determining LAGs autonomy, democratic participation, development and justice outcomes over the last two LEADER phases?", it has emerged that several local factors interweave with governance factors to influence the flow and outcome of participatory actions. These range from the social, psychological and financial position of the recipient community, through to the resourcefulness of the area (economic resources, availability of various kinds of expertize: human capital to management skills) enabling or hindering a successful infusion of local knowledge into the development process. These conditions are influenced by national-level procedural rules (prescription and control of participation), legacies of the past as well as by various aspects of accessibility, including physical (distances, transport infrastructure), financial (affordability of travel, number of personnel) and procedural (central or territorially dispersed locations of organized participatory actions).

In terms of justice outcomes, LEADER is a programme which makes available small grants for rural actors and thus its direct impact on spatial injustice is necessarily limited. However, if the distributional aspect of LEADER, linked to development, is considered, the aim of contributing to a more just territorial distribution of resources represented a specific focus in both case studies. In addition to territorial targets, social targets were clear in the NULAG case in the first iteration and in the Balaton Uplands LAG in the second, both having a particular focus on rural youth. The most vulnerable social and minority groups were not addressed, which is understandable, if we consider the programmelevel thematic agendas of LEADER in the two most recent iterations. If smallscale entrepreneurship, rural tourism and networking of these actors are addressed, such as, for example in case of the Balaton Uplands LAG, it is necessarily the small business-owning class which gains most benefit from the Programme. This is, however, a legitimate and adequate purpose of rural development, especially in a post-state socialism context. This fact does not detract from the failure of LEADER to consider how systems of governance and dimensions of power may act to the benefit of existing power holders, emerging repeatedly in the literature (Commins, Keane 1994). Those who are already well resourced, skilled and networked can access LEADER programmes and cope with the demands of the grant applications process, whereas lower skilled, more isolated actors with less capital behind them may struggle to engage and if engaged, to win grants (Shucksmith 2000; Ellis 2001).

We have also mentioned in this paper a primary condition imposed by higher-level governance, namely the financial endowment of the LEADER 
Programme. This remained at the mandatory minimum level of $5 \%$ of the RDP, resulting in modest levels of funding for the individual LAGs in both England and in Hungary, where both the small rate of allocation of resources (the 5\%) and wide coverage (both programmes expanded to all rural areas, Hungary in Phase 1 and England in Phase 2) contribute to LAG-level financial endowments. This condition sets limitations on the power and responsibility wielded by LAGs over the scale of impact of local development they might achieve. In light of this, high expectations of sound, area-related development must exceed the realities. What can be expected, however, is niche-based, unique and place-shaped development, explored through participatory actions and absorbed local knowledge and transmitting resources to those stakeholders for whom other funding instruments are not available. This can be said to have been achieved by NULAG and the Balaton Uplands LAGs for Phase 1 implementation but was not the case because of different kinds of circumstances in Phase 2.

In answering our second research question "What is the impact of nationallevel recentralization on the governance of LEADER programmes over the case study period?", we consider that LEADER as a policy tool, which is implemented in a decentralized manner, operates necessarily within a hierarchical institutional framework, which generates procedures and excersises control.

LEADER has been interpreted through diverse discourses. According to the critical social scientists quoted above, LEADER has been shaped by the neoliberalization of governance that was a prevailing trend at the time of its origins in the early 1990s and can operate in favour of uneven development. Neoliberal discourses are regarded by such critics as scaling down responsibility to local levels without providing these lower government levels with an appropriate stock of resources, degree of autonomy and power. Governing approaches and epochal trends are of course always influential but empirical evidence suggests that the concrete drivers of decentralization differ by macroregion in Europe. The allocation or withdrawal of resources can be triggered by different contexts as well. In the former state socialist countries, and in Hungary specifically, decentralization of state administration was a reaction to the failing, over-centralized socialist state structures, rather than a manifestation of ideological neoliberalism. Independent of the LEADER Programme, withdrawal of the already meagre resources aimed at financing development actions from local governments in 2009 was a desperate step, arguably enforced by the critical status of the heavily indebted country in the context of the global financial crisis. The fact that these normative funds have never returned to the local level has been in line with recentralization (Ladner, Keuffer, Baldersheim 2016) - the opposite trend to neoliberalization - and an extreme level of decrease in local autonomy taking place during the conservative governments that have been in power since 2010. 
Nevertheless, one of the investigated LAGs, that operating in Hungary, was autonomous enough to create and implement its LDS within certain parameters set by the RDP and the managing institutional environment; the other, operating in the British context, was not. The LEADER Programme was challenged in both countries either by reduction of LAG-level funding (in England, mainly due to considerable expansion of the scheme in Phase 2) or reduction of the scope of decentralized rural development measures (in Hungary). EU-level sanction of the funds due to adverse audit in Phase 1 also contributed to shrinking funding of LEADER in England, while in Hungary the reasons were a consequence of political shift, changing concepts from governance to government, from decentralization to recentralization, and the influence of changes in Hungary's rural policies. Direct intervention from the ministerial level to the LAGs' strategies was mainly related to the post-crisis austerity response in England. In Hungary, the unprecedentedly strict bureaucratic control, which seriously constrained the LAGs' autonomy in the first years of Phase 1 (but had been eased by 2012) permitted successful implementation of LDSs in most LAGs but was a considerable source of frustration for LAGs and their clients (beneficiaries) alike (Csurgó, Kovách 2018; Finta 2020; Kovács 2018).

In cases where the extended bureaucracy is coupled with mismanagement at the upper levels of government, however, the execution of a LDS can be seriously threatened - for example, where the tendering or approving processes are delayed for years, or certain measures are not tendered at all, or they are tendered too late, which was typically the case with the domestic and international co-operation LEADER projects in Hungary. The unacceptable delay of the centrally orchestrated tendering process in both Hungary and England in Phase 2 provides a further example of the vulnerability of LAGs to central-level management processes that hinder LAG-level autonomy profoundly. This vulnerability was evident in both cases but certainly more extreme in Hungary: according to the mid-term evaluation of the Hungarian LEADER programme, in December 2018, four years after the start of the programming period, the amount of EU money absorbed was precisely zero HUF (Nemes, Magócs 2020).

\section{Conclusion}

Our case studies show both the 'light' and 'shadow' potentials in LEADER. They uncover several common features as well as differences driven by deviations regarding maturity and institutional contexts. They also echo the findings of earlier studies to highlight the programme's design flaws that make it vulnerable to co-option by the most powerful players in rural development, be they 'the usual suspects' of privileged places and players in the local area, or local and national authorities. Paradoxically, according to the result of the comparison of 
autonomy levels of the investigated cases, the NULAG case, which operates in the context of an advanced liberal democracy, appeared to be less autonomous. This finding was due not only to the unprecedented intervention by the ministerial level of administration to LAG matters in the second phase of NULAG, but also relates to the historical pathway and institutional environment. This LAG operated in close dependence on local authorities whose behaviour might be Janus-faced, providing services and capacities on the one hand, but trying to influence LAG matters on the other.

Linking the empirical findings from the case studies with the literature on autonomy, decentralization, participation and democracy reviewed in the paper, it can be said that although devolving funds to local representatives on LAG Boards may represent a form of decentralization, these two cases have clearly shown that when not specifically designed for at a higher programme level, autonomy is easily eroded in particular political and economic contexts. Although to different extents, the expectations raised by the LEADER principles, in confrontation with the reduced powers of 'initiation' and 'immunity' and the reduced capacities for participation seen in the 2014-2020 LEADER phase, must represent a lost opportunity for deepening local democracy and expanding engagement and participation in the rural areas where these actions took place. This may be especially regrettable in the context of England, which besides its highly centralized governance system, has the largest catchment scale of local government in Europe, and where, for almost a quarter of a century before the most recent programme, LEADER represented a rare opportunity for rural communities to take coordinated action on locally owned and distinctive futures.

The distortions revealed, the direct top-down intervention of the government into LAG matters in England and the immense delay caused by the central level management in Hungary cannot be considered as either a smooth or appropriate implementation of the LEADER Programme. This reflects the weak capability of the supranational (EU) level to ensure a relatively balanced delivery of the Programme across member states, notwithstanding the interruption to management during the inter-programme periods, which has always and in both countries created serious problems. Unfortunately, due to Brexit, British LAGs have now been dissolved: for them LEADER has become history. But if the purpose of LEADER is to be achieved for the remaining member states, it will be important to introduce measures to assure cooperation between governing bodies, to increase LAG-level autonomy and to foster more reliable external operational conditions for LAGs.

\section{Acknowledgements}

The methodology and approach of the case studies whose secondary interpretation provides the empirical background for this article was supported by an EU H2020 project (grant number 727097), 
led by James W. Scott, coordinated by the University of Eastern Finland. The authors are grateful to representatives and employees of the investigated LEADER LAGs as well as all participants responding to our long list of interview questions.

Thanks are also due to the RELOCAL teams at the Centre for Economic and Regional Studies and Newcastle University, in particular Gusztáv Nemes and Mark Shucksmith, for all inputs to the original case studies and for contributions to the virtual workshops on autonomy in LEADER carried out for this study.

We also thank our reviewers whose helpful comments supported us in finalising this paper.

A tanulmány a RELOCAL (Resituating the Local in Cohesion and Territorial Development) H2020 kutatás keretében készült (No. of Grant Agreement 727097).

\section{Notes}

1 A NATURAMA Szövetség Akciócsoportjainak javaslatai az UMVP III. IV. tengelye intézkedéseinek hatékonyabb megvalósítása érdekében. [Suggestions of the NATURAMA Alliance for the more effective implementation of III-IV axes of the RDP], 2010. http:// leadercontact.com/images/stories/https__leaderkontakt.pdf

2 Resituating the Local in Cohesion and Territorial Development (RELOCAL) Grant number 727097.

3 The nations of the UK - England, Scotland, Wales and Northern Ireland (of which the latter three can be described as 'devolved') - each have power over the framing of the LEADER programme in their nation (but not the funding, which is set at UK level). Hence where relevant in this paper, it is the England rather than UK LEADER scheme that is referred to.

4 Area-based local development strategies; bottom-up elaboration and implementation of strategies; local public-private partnerships, local action groups; integrated and multi-sectoral actions; innovation; cooperation; networking (European Commission [EC] 2006)

5 The case study material Zamfir's critique is based upon was also conducted as part of the RELOCAL project (Zamfir 2019).

6 During LEADER Plus (the name of the programme from 2000-2006), organizational forms of LEADER LAGs varied in Hungary; uniformity was introduced by the 2007-13 programming cycle, when it was required that the new LAGs be (re)established as independent associations.

7 The four measures delivered in a devolved manner were: Village renewal, Cultural heritage, Developing micro-enterprises, Rural tourism. Two measures (Village buses, Integrated Rural Centres) were put to a centrally steered tender process.

8 In the 2007-2013 iteration, parallel with 'mainstreaming' LEADER, a significant extension of coverage of LEADER LAGs was rather common across the EU rural areas (Thuesen 2010).

9 Priority 6 of the RDP aimed at "Promoting social inclusion, poverty reduction via development of small enterprises and job creation, local development, enhanced accessibility and use of ITC".

10 The case study approach is explained in more detail in the case study reports and on the project website (https:relocal/eu).

11 Answering this study's two research questions in this section is mainly based on the materials presented above, but inevitably also draws upon the longer and more detailed presentation of the case studies in the original reports for the RELOCAL project (Kovács, Nemes 2019; Brooks, Shucksmith, Madanipour 2019). 


\section{References}

Andersson, K., Kovách, I. (2010): Lagging behind or LEADER in local democracy? An assessment of LEADERtype development projects as a tool for democratic integration in the contested countryside. SSKH Reports and Discussion Paper Nr. 3/2010. Swedish School of Social Science, Helsinki

Annibal, I., Bosworth, G., Carroll, T., Price, L., Sellick, J., Shepherd, J. (2013): A Review of the Leader Approach for Delivering the Rural Development Programme for England. A Report for DEFRA. DEFRA, h.n.

Atterton, J., Mc Morran, R., Glass, J., Jones, S., Meador, E. (2020): The Role of the LEADER Approach PostBrexit: Technical Report. Scotland's Rural College

Blondel, C., Evrard, E., (2020): Empirical Findings from Case Studies on Regional Autonomy and Spatial Justice. University of Eastern Finland

Brooks, E., Shucksmith, M., Madanipour, A., (2019): The Northumberland Uplands Local Action Group (NULAG): LEADER in Sparsely Populated Northern England, United Kingdom. RELOCAL Case Study $\mathrm{N}^{\circ} 31 / 33$. University of Eastern Finland

Brown, G., Carnegie Trust (2010): Rural Development and the LEADER Approach in the UK and Ireland. Carnegie UK Trust Research Paper. Andrew Carnegie Trust, Fife

Chardas, A. (2017): Local governance in the age of austerity in Greece and the impact of the EU leader approach in the region of Peloponnesus. Journal of Balkan and Near Eastern Studies, 6., 628-644. https://doi.org/g5xj

Clark, G. L. (1984): A theory of local autonomy. Annals of the Association of American Geographers, 2., 195-208. https://www.jstor.org/stable/2569279 (21.07. 2021.)

Commins, P., Keane, M. (1994): Developing the Rural Economy: Problems, Programmes and Prospects. New Approaches to Rural Development III, National Economic and Social Council, Dublin

Csurgó, B., Kovách, I. (2015): The LEADER programme in Hungary - Bottom-up development with top-down control? In: Granberg, L., Andersson, K., Kovách, I. (eds.): Evaluating the European Approach to Rural Development: Grass-roots Experiences of the LEADER Programme. Ashgate, 53-78.

Dabla-Norris, E. (2006): The challenge of fiscal decentralization in transition countries. Comparative Economic Studies, 48., 100-131. https://doi.org/dxfjpt

Dax, T., Machold, I., Bauchinger, L. (2020): Case Study Mansfeld-SüdHarz, Germany. ESCAPE. European Shrinking Rural Areas. Final Report. Annex 8. https://www.espon.eu/sites/default/files/attachments/ ESPON\%20ESCAPE\%20Final\%20Report\%20Annex\%2008\%20-\%20CS\%20Mansfeld-S\%C3\%BCdharz_ Germany.pdf (11.07. 2021.)

Devas, N., Delay, S. (2006): Local democracy and the challenges of decentralising the state: An international perspective. Local Government Studies, 5., 677-695. https://doi.org/fnjw22

Ellis, A. (2001): Power and Exclusion in Rural Community Development: The case of LEADER II in Wales. PhD Thesis, Department of Geography, University of Swansea

Erlingsson, G. O., Ödalen, J. (2017): A normative theory of local government: Connecting individual autonomy and local self determination with democracy. Lex Localis - Journal of Local SelfGovernment, 2., 329-342. https://doi.org/g5xm

Esparcia, J., Escribano, J., Serrano, J. J. (2015): From development to power relations and territorial governance: Increasing the leadership role of LEADER Local Action Groups in Spain. Journal of Rural Studies, 42., 29-42. https://doi.org/ggfm42

European Commission (2006): The LEADER Approach. A basic guide. European Commission. https:// enrd.ec.europa.eu/sites/default/files/2B953E0A-9045-2198-8B09-ED2F3D2CCED3.pdf (Uploaded: 21. 07. 2021.)

European Network for Rural Development (2016): Factsheet Prepared for the ENRD Workshop on LEADER/ CLLD and Networking Supporting Social Inclusion in Rural Areas. https://enrd.ec.europa.eu/sites/ enrd/files/w8_factsheet1_leader_clld.pdf (Uploaded: 21. 07. 2021.)

Finta I. (2020): A vidékfejlesztés lépcsői a rendszerváltástól napjainkig. Tér és Társadalom, 4., 172-177. https://doi.org/g5xn

Fleurke, F., Willemse, R. (2006): Measuring local autonomy: A decision-making approach. Local Government Studies, 1., 71-87. https://doi.org/dmtc79 
Furmankiewicz, M., Thompson, N., Zielinska, M. (2010): Area-based partnerships in rural Poland: The post-accession experience. Journal of Rural Studies, 1, 52-62. https://doi.org/crnbvg

Furmankiewicz, M., Knieć, W., Atterton, J. (2015): Rural governance in the new EU member states: The experience of the Polish LEADER+ pilot programme (2004-2008). In: Buček, J., Ryder, A. (eds.): Governance in Transition. Springer Verlag, Dordrecht

Game, C. (2016): Decentralisation and devolution in the United Kingdom. In: Sadioglu, U., Dede, K. (eds.): Comparative Studies and Regionally-Focused Cases Examining Local Governments. IGI Global, Hershey, PA.

Granberg, L., Andersson, K., Kovách, I. (2015): Introduction: LEADER as an experiment in grass-roots democracy. In: Granberg L., Andersson K., Kovách I. (eds.): Evaluating the European Approach to Rural Development: Grass-roots Experiences of the LEADER Programme. Ashgate, 1-12.

Husu, H. M., Kumpulainen, K. (2019): Promoting neoliberal ideology in Finnish rural community development: the creation of new moral actors. Local Government Studies, 6., 893-912. https:// doi.org/g5xp

Johnson, C. (2001): Local democracy, democratic decentralisation and rural development: Theories, challenges and options for policy. Development Policy Review 4., 521-532. https://doi.org/fh2bzv

Kákai, L. (2020). From financial centralisation to political centralisation. The focal points of the municipal reforms from the transition until present day Hungary. In: Nunes-Silva C. (Ed.) Contemporary Trends in Local Governance: Reform, Cooperation and Citizen Participation. Springer, Dordrecht, 67-86.

Kovács D. (2018): A LEADER program 2010-2018 közötti időszakának néhány jellemzője Magyarországon. Észak-magyarországi Stratégiai Füzetek, 3, 31-54.

Kovács, K., Nemes, G. (2019): The Balaton Uplands. LEADER Local Action Group, Hungary. RELOCAL Case Study $N^{\circ}$ 16/33. University of Eastern Finland. RELOCAL. https://RELOCAL. relocal.eu/wp-content/ uploads/2019/05/16_HU_Case_3_Balaton_Uplands_LEADER_LAG.pdf. (Uploaded:10. 06. 2021.)

Ladner, A., Keuffer, N., Baldersheim, H. (2015): Self-rule Index for Local Authorities. Final Report for the European Commission. European Commission. https://ec.europa.eu/regional_policy/sources/ docgener/studies/pdf/self_rule_index_en.pdf (Uploaded:10.06.2021.)

Ladner, A., Keuffer, N., Baldersheim, H. (2016): Measuring Local Autonomy in 39 Countries (1990-2014). Regional and Federal Studies, 3., 321-357. https://doi.org/c4ck

Loewen, B. (2018): From decentralization to re-centralization: Tendencies of regional policy and inequalities in Central and Eastern Europe. Administrative Culture, 2., 103-126. https://doi.org/g5xq

Lowe, P., Phillipson, J., Proctor, A., Gkartzios, M. (2019): Expertise in rural development: A conceptual and empirical analysis. World Development, 116., 28-37. https://doi.org/c6xr

Macken-Walsh, A., Curtin, C. (2013): Governance and rural development: The case of the Rural Partnership Programme (RPP) in post-socialist Lithuania. Sociologia Ruralis, 2., 246-264. https://doi.org/g5xr

March, J., Olsen, J. (1989): Rediscovering Institutions: The Organizational Basis of Politics. Free Press, New York Marquardt, D., Möllers, J., Buchenrieder, G., (2012): Social networks and rural development: LEADER in Romania. Sociologia Ruralis, 4., 398-431. https://doi.org/f4bspz

Mill, J. S. (1861): Considerations on Representative Government. Parker, Son, \& Bourn, London

Muller, O., Sutter, O., Wohlgemuth, S. (2020): Learning to LEADER. Ritualised performances of 'participation' in local arenas of participatory rural governance. Sociologia Ruralis, 1., 222-242. https://doi.org/g5xs

Munck af Rosenschöld, J., Löyhkö, J. H. (2015): LEADER and local democracy: A comparison between Finland and the United Kingdom. In: Granberg, L., Andersson, K., Kovách, I. (eds.): Evaluating the European Approach to Rural Development: Grass-roots Experiences of the LEADER Programme. Ashgate, 13-32.

A NATURAMA Szövetség Akciócsoportjainak javaslatai az UMVP III. IV. tengelye intézkedéseinek hatékonyabb megvalósítása érdekében. Egyeztetett változat [Suggestions of the NATURAMA Alliance for the more effective implementation of 3-4 axes of the RDP] (2010). http:// leadercontact.com/images/stories/https_leaderkontakt.pdf (Uploaded: 09. 09. 2021)

Navarro, F., Cejudo, E., Maroto, J. (2016): Participation of disadvantaged groups and governance in the LEADER and PRODER programmes in Andalucía, Spain. Studies in Agricultural Economics, 118., 47-54. https://doi.org/g5xt 
Nemes G., Magócs K. (2020): Közösségi alapú vidékfejlesztés Magyarországon - A LEADER-intézkedés eredményei a 2014-2020-as tervezési időszak félidejében. Gazdálkodás, 5., 416-434. https:// doi.org/g5xv

Osti, G. (2015): LEADER LAGs: Neocorporatist local regimes or examples of economic democracy? In: Granberg, L., Andersson, K., Kovách, I. (eds.): Evaluating the European Approach to Rural Development: Grass-roots Experiences of the LEADER Programme. Ashgate, 149-164.

Pálné Kovács, I. (2020): Governance without power? The fight of the Hungarian counties for survival. In: Silva, C. N. (ed.). Contemporary Trends in Local Governance. Springer, Dordrecht, 45-66.

Pálné Kovács I. (2021): A centralizáció és a perifériák fejlődési esélyei. Tér és Társadalom, 4., 215-240. https://doi.org/10.17649/TET.35.4.3372

Parry, G. ,Moyser, G. (1994): More participation, more democracy? Beetham, D. (ed.), Defining and Measuring Democracy. Sage, London, 44-62.

Peck, J., Tickell, A. (2002): Neoliberalizing Space. Antipode, 3., 380-404. https://doi.org/drnfbk

Rodríguez-Pose, A., Krøijer, A. (2009): Fiscal decentralization and economic growth in Central and Eastern Europe. Growth and Change, 3., 387-417. https://doi.org/dfkkmx

Shucksmith, M. (2000): Endogenous development, social capital and social inclusion: Perspectives from LEADER in the UK. Sociologia Ruralis, 2., 208-218. https://doi.org/bdgp6k

Shucksmith, M. (2010): Disintegrated rural development? Neo-endogenous rural development, planning and place-shaping in diffused power contexts. Sociologia Ruralis, 1., 1-14. https:// doi.org/d2jrp4

Shucksmith, M., Brooks, E., Madanipour, A. (2021): LEADER and spatial justice. Sociologia Ruralis, 2., 322-343. https://doi.org/g5xw

Silva, C. N. (ed.) (2020): Contemporary Trends In Local Governance. Springer, Dordrecht

Smith, J. T. (1851): Local Self-Government and Centralization. John Chapman, London

Thuesen, A. A. (2010): Is LEADER elitist or inclusive? Composition of Danish LAG boards in the 20072013 rural development and fisheries programmes. Sociologia Ruralis, 1., 1-15. https://doi.org/ bvfs92

Thuesen, A. A. (2015): The democratic capabilities of and rhetoric on LEADER LAGs in the EU - The Danish cse. In: Granberg, L., Andersson, K., Kovách, I. (eds.): Evaluating the European Approach to Rural Development: Grass-roots Experiences of the LEADER Programme. Ashgate, 79-94.

Van Houwelingen, P. (2018): Local autonomy, municipal size and local political participation in Europe. Policy Studies, 2., 188-203. https://doi.org/g5xx

Weck, S., Kamuf, V., Krehl, A., Schmitt, P., Borén, T., Kovács, K. Virág, T., Tagai, G., Blondel, C., Evrard, E., Nienaber, B. (2018). Methodological framework for case study research (the case study manual). University of Eastern Finland, Unpublished

Work, R. (ed.) (2002): The Role of Participation and Partnership in Decentralised Governance: A Brief Synthesis of Policy Lessons and Recommendations of Nine Country Case Studies on Service Delivery for the Poor. UNDP, New York

Zamfir, G. I. (2019): Micro-Regional Association Mara-Natur in Maramures County, Romania. RELOCAL Case Study $N^{\circ} 26 / 33$. University of Eastern Finland

Zamfir, G. I. (2020). A knife to a gunfight: endogenous development through LEADER as contradictory policy prescription. Studia Universitatis Babes-Bolyai Sociologia, 1., 43-68. https://doi.org/g5xz 